\title{
LETTER
}

\section{Jadeite-quartz-K-feldspar rocks in the Kamuikotan zone, Japan}

\author{
Yukihisa OsAdA ${ }^{*}$, Hirokazu MAEKAwA* and Koshi YAMAMOTo** \\ *Graduate School of Science, Osaka Prefecture University, Sakai, Osaka 599-8531, Japan \\ ${ }^{* *}$ Graduate School of Environmental Studies, Nagoya University, Nagoya 464-8601, Japan
}

\begin{abstract}
Several tens of float blocks of jadeite-quartz-K-feldspar rocks were recently found in and around serpentinite masses in the Kamuikotan Gorge area of the central Kamuikotan zone, Japan. They consist mainly of jadeite $\left(\mathrm{Jd}_{95-100}\right)$, quartz, $\mathrm{K}$-feldspar, phengite, and lawsonite. Two stages of metamorphism are recognized. The metamorphic conditions during the first and the second stages are estimated at about $250-350{ }^{\circ} \mathrm{C}$ and more than 1.1 GPa, and $200-300{ }^{\circ} \mathrm{C}$ and $0.4-0.7 \mathrm{GPa}$, respectively. The rocks are relatively fine-grained, acidic in composition, and characteristically have many jadeitized pseudomorphs of probable rapakivi feldspar, suggesting a hypabyssal fine-grained granite or granite porphyry origin. $\mathrm{K}$-feldspar-bearing granitic rocks have never been reported from the Kamuikotan zone. The discovery of jadeite-quartz-K-feldspar rocks in the zone provides important information about the source of the metamorphic protoliths. The inference is that these materials formed by the activity of felsic magma, which existed near the trench during Late Jurassic to Cretaceous time.
\end{abstract}

Keywords: Jadeite, Serpentinite, Mélange, Kamuikotan, Blueschist, Rapakivi

\section{INTRODUCTION}

The Kamuikotan zone runs north to south along the axial zone of Hokkaido, Japan (Fig. 1). It extends for more than $300 \mathrm{~km}$ with a maximum width of $30 \mathrm{~km}$. The bedrock consists mainly of Jurassic to Early Cretaceous high P/T metamorphic rocks and serpentinized peridotites. Most of the structural, petrologic, and chemical data suggest that the region represents the trace of an ancient consuming plate boundary with westward-dipping subduction. The zone often comprises serpentinite mélange with various kinds of tectonic blocks, such as blueschist, amphibolite, metasediment, and greenstone (pillow and massive lava, and their clastic equivalents). The modes of occurrence of the mélange suggest that the tectonic blocks have been incorporated into serpentinite by tectonic mixing during both the subduction and the uplift stages (Maekawa, 1989).

In the Kamuikotan Gorge area, about $50 \mathrm{~km}$ west of Asahikawa City, rocks composed mainly of jadeite and quartz are sporadically found as float blocks up to $2 \mathrm{~m}$ in diameter within a region where serpentinites are exclusively dominant (Gouchi, 1983; Takayama, 1986). The formation of these jadeite-quartz rocks needs remarkably high $\mathrm{P} / \mathrm{T}$ metamorphic conditions. In order to determine

doi:10.2465/jmps.060831a

H. Maekawa, maekawa@p.s.osakafu-u.ac.jp Corresponding author Y. Osada, s_osada@p.s.osakafu-u.ac.jp the nature of their protoliths, it is important to understand the tectonic environment and the style of metamorphism in the Kamuikotan zone. Takayama (1986) suggested that the floats found in the Etanbetsu-Daihassen River were derived from plagiogranite and pelitic rock.

A different type of jadeite-quartz rock was recently found by this study in the Osamunai-Horonai River, occurring as several tens of boulders up to $1.5 \mathrm{~m}$ in diameter. These rocks are acidic in composition, and characteristically contain pseudomorphs of $\mathrm{K}$-feldspar with a plagioclase mantle. This rock type, referred to as "jadeitequartz-K-feldspar rock", seems to be important to the understanding of the tectonic environment in and around the subduction zone during the Kamuikotan blueschist facies metamorphism. Consequently, in this paper we describe their petrologic characteristics and discuss their origin and metamorphic $\mathrm{P} / \mathrm{T}$ history.

\section{GEOLOGIC SETTING}

The low-grade high $\mathrm{P} / \mathrm{T}$ metamorphic rocks are widely exposed in the Kamuikotan Gorge area, west of Asahikawa City, central Hokkaido. The metamorphism is characterized by the common occurrence of lawsonite, aragonite, and sodic pyroxene, and belongs to a subfacies of the lawsonite-albite facies, in which aragonite is stable (Takayama, 1986). Late Cretaceous to Early Paleogene K$\mathrm{Ar}$ ages were obtained for metamorphic phengites from 


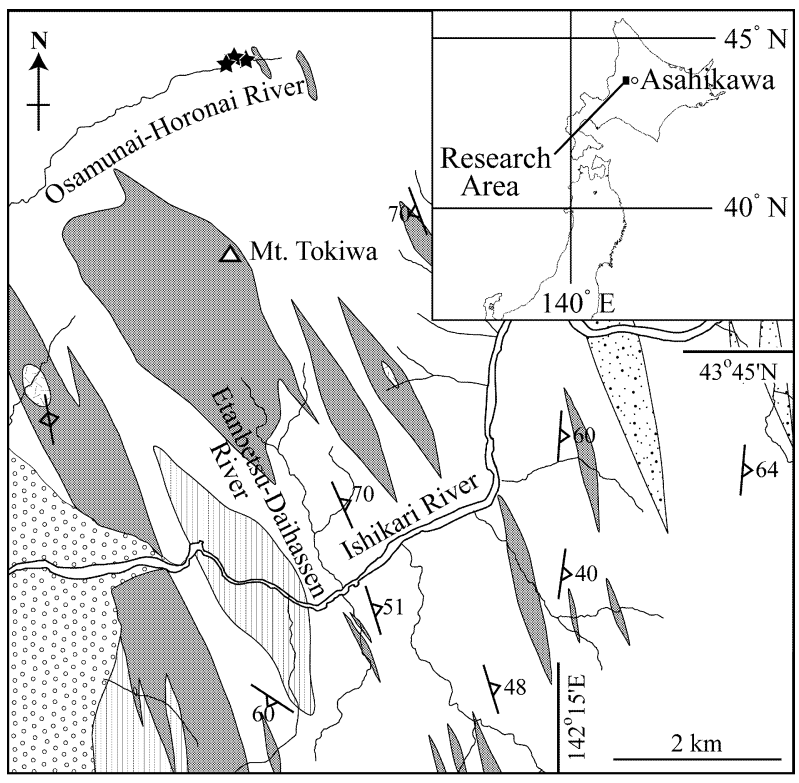

Kamuikotan metamorphic rocks

$$
\begin{aligned}
& \square \text { Greenschist } \square \text { Serpentinite } \\
& \square \text { Pelitic schist } \square \text { Amphibolite } \square \text { Psammitic schist }
\end{aligned}
$$

Figure 1. Geologic map of the Kamuikotan Gorge area. The stars indicate the locations of jadeite-quartz-K-feldspar rocks.

pelitic schists and rocks by Sakakibara and Ota (1994). The metamorphic protoliths are mafic lava and pyroclastic material, ultramafic, pelitic and psammitic rock, limestone, and chert. The planar fabric of each unit, such as bedding, schistosity, or shear planes, trends $\mathrm{N}-\mathrm{S}$ and dips $\mathrm{E}$ or $\mathrm{W}$ at a high angle, although the fabric is much less developed in the eastern area. Due to the complexity of rock outcrop, geological interpretations vary depending upon the researchers (Gouchi, 1983; Takayama, 1986; Sakakibara and Ota, 1994), and remain controversial. We will discuss this elsewhere.

\section{JADEITE-QUARTZ-K-FELDSPAR ROCKS}

The jadeite-quartz-K-feldspar rocks were found as float blocks up to $1.5 \mathrm{~m}$ in diameter in the Osamunai-Horonai River in the western part of the Kamuikotan Gorge region. Only a few small exposures of pelitic schists are found in the area, and we could not find any exposure of serpentinite except upstream (Fig. 1). Serpentinite is poorly exposed due to its high susceptibility to weathering, so we could not confirm its exact distribution, and we may have underestimated its extent in Figure 1.

Considering the intimate association of similar jadeite-quartz rocks with serpentinite in the Kamuikotan Gorge area (Gouchi, 1983; Takayama, 1986) and the necessity for extremely high $\mathrm{P} / \mathrm{T}$ conditions in their formation, these jadeite-quartz-K-feldspar rocks are thought

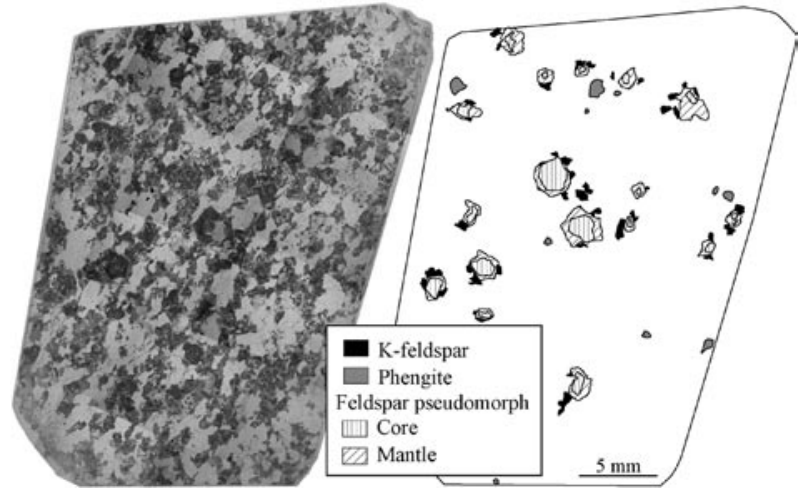

Figure 2. A thin section photograph (left) and a schematic sketch (right) of jadeite-quartz-K-feldspar rock.

to have been tectonic blocks entrained from depth by serpentinite. They are massive and do not have any foliation. They consist of sodic pyroxene $\left[\mathrm{Jd}_{95-100}(=95-100 \mathrm{~mol} \%\right.$ jadeite component) and $\mathrm{Jd}_{10-60}$, quartz, $\mathrm{K}$-feldspar, phengite, lawsonite, albite, sodic-calcic amphibole, pumpellyite, and grossular, with minor amounts of allanite, titanite, rutile, zircon, ilmenite, and apatite.

A peculiar texture is recognized in these rocks such that relatively coarse-grained pseudomorphs 1-2 mm in diameter are scattered in a matrix that is mainly an aggregate of fine-grained jadeite and quartz crystals (Fig. 2). Although the pseudomorphs are composed mainly of jadeite, they always occur as aggregates of jadeite, quartz, $\mathrm{K}$-feldspar, and phengite in the core, and of jadeite, quartz, lawsonite, $\mathrm{K}$-feldspar, and phengite in the enclosing mantle. Slender 10-20 $\mu \mathrm{m}$ randomly orientated lawsonite crystals are characteristically abundant in the mantle (Fig. 3). The mineral association between core and the exterior suggest that the pseudomorphs were initially $\mathrm{K}^{-}$ feldspar rimmed by plagioclase. Compositions inferred from the ratios of each constituent mineral in the core and surround are roughly consistent with $\mathrm{K}$-feldspar and plagioclase. Broad beam analyses of the pseudomorphs by EPMA suggest that the core and rim can be roughly estimated to have had compositions of albite-orthoclase and albite-anorthite solid solutions, respectively.

\section{Mineralogy}

Pyroxene. Two kinds of sodic pyroxene are commonly recognized (Fig. 4 and Table 1). One has a 95-100 mol\% jadeite component. It occurs as a pseudomorph replacement of feldspar and is also found in the matrix as a finegrained isolated crystal. It was partly or mostly replaced by albite during later second stage metamorphism (Fig. $3 \mathrm{~B})$. Another kind of sodic pyroxene is found around the rim of the feldspar pseudomorph $\left(\mathrm{Jd}_{10-60}\right)$ and in the 


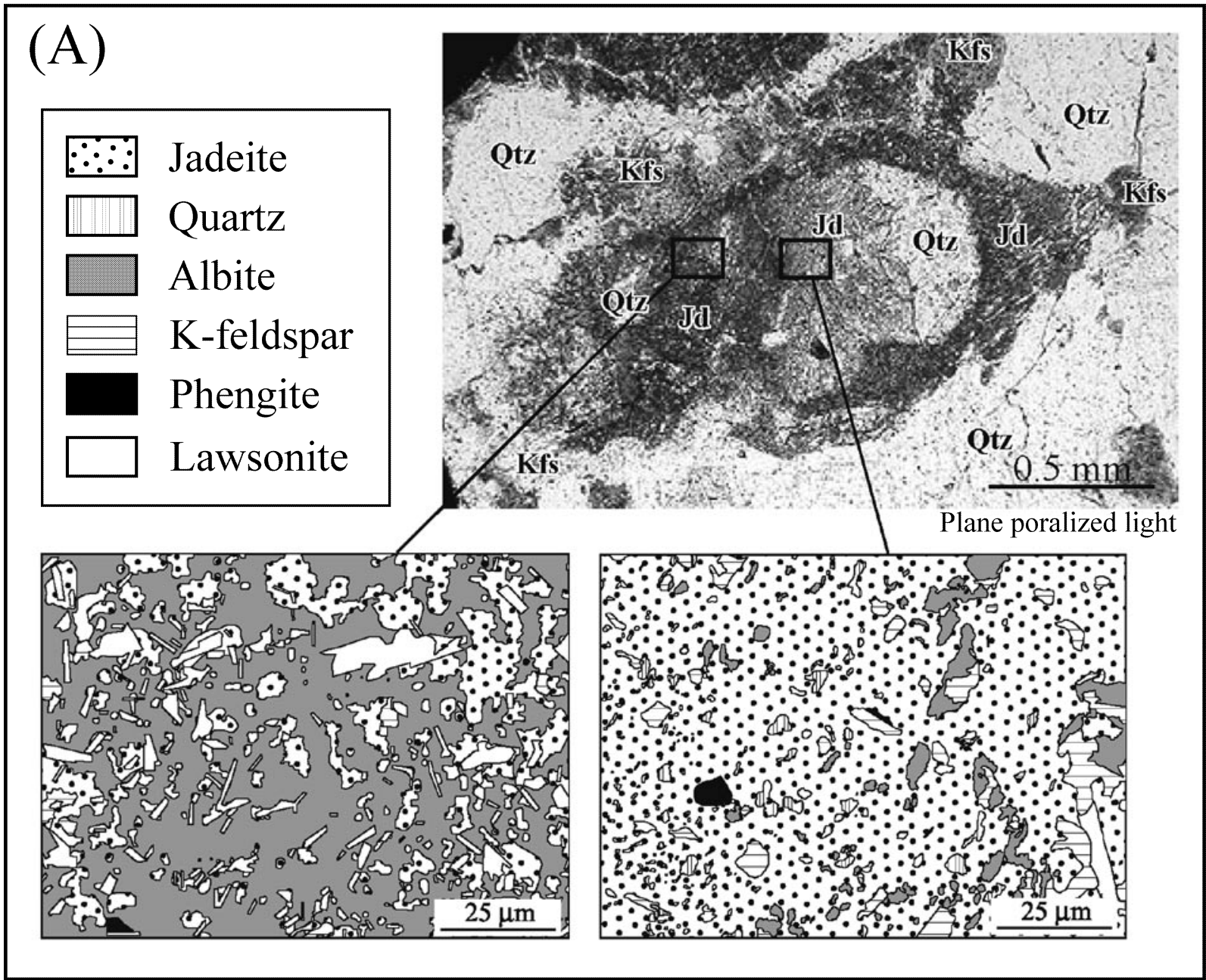

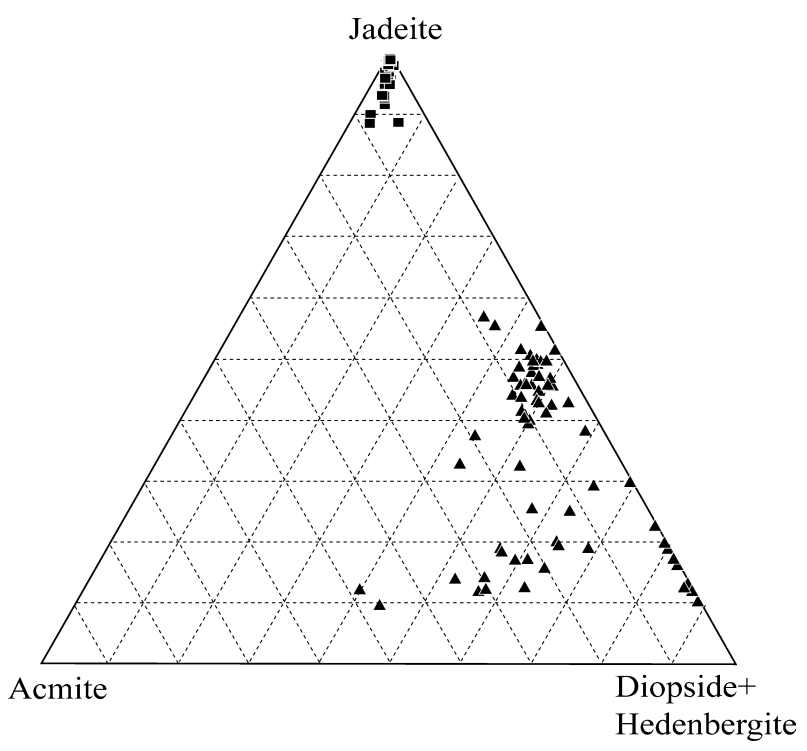

Figure 4. Chemical compositions of sodic pyroxene in the jadeiteacmite-diopside + hedenbergite ternary diagram. Solid square and triangle indicate sodic pyroxene of the first and second stage metamorphism, respectively. Sodic pyroxenes on the rim of ilmenite are omitted in this figure.
Figure 3. Modes of occurrence of feldspar pseudomorphs. (A) The and rare lawsonite, whereas the mantle consists of jadeite, lawzation during the second stage metamorphism is much higher in $\mathrm{K}$-feldspar, albite, and phengite, whereas the mantle consists of feldspar pseudomorph does not contain quartz, which was prob-

matrix $\left(\mathrm{Jd}_{10-35}\right)$. The jadeite components of the sodic pyroxene around the rim of the pseudomorphs vary remarkably, probably due to epitaxial growth. Sodic pyroxene found on the rim of ilmenite is poor in jadeite $\left(\mathrm{Jd}_{0-6}\right)$ and rich in acmite $\left(\mathrm{Ac}_{74-92}\right)$. It is considered that the jadeite components of sodic pyroxene, which coexists stably with quartz and albite, are 10-35 mol\%.

Amphibole. Sodic-calcic winchite to ferrowinchite, and riebeckite are found. Sodic-calcic amphiboles are commonly found with stilpnomelane as an aggregate of finegrained acicular crystals. Riebeckite occurs around the rim of ilmenite.

Lawsonite. This mineral occurs only at the outer part of feldspar pseudomorphs as euhedral prismatic crystals. $\mathrm{Fe}_{2} \mathrm{O}_{3}$ contents are low and less than $0.3 \mathrm{wt} \%$ (Table 1).

Phengite. This is found in both the matrix and feldspar 


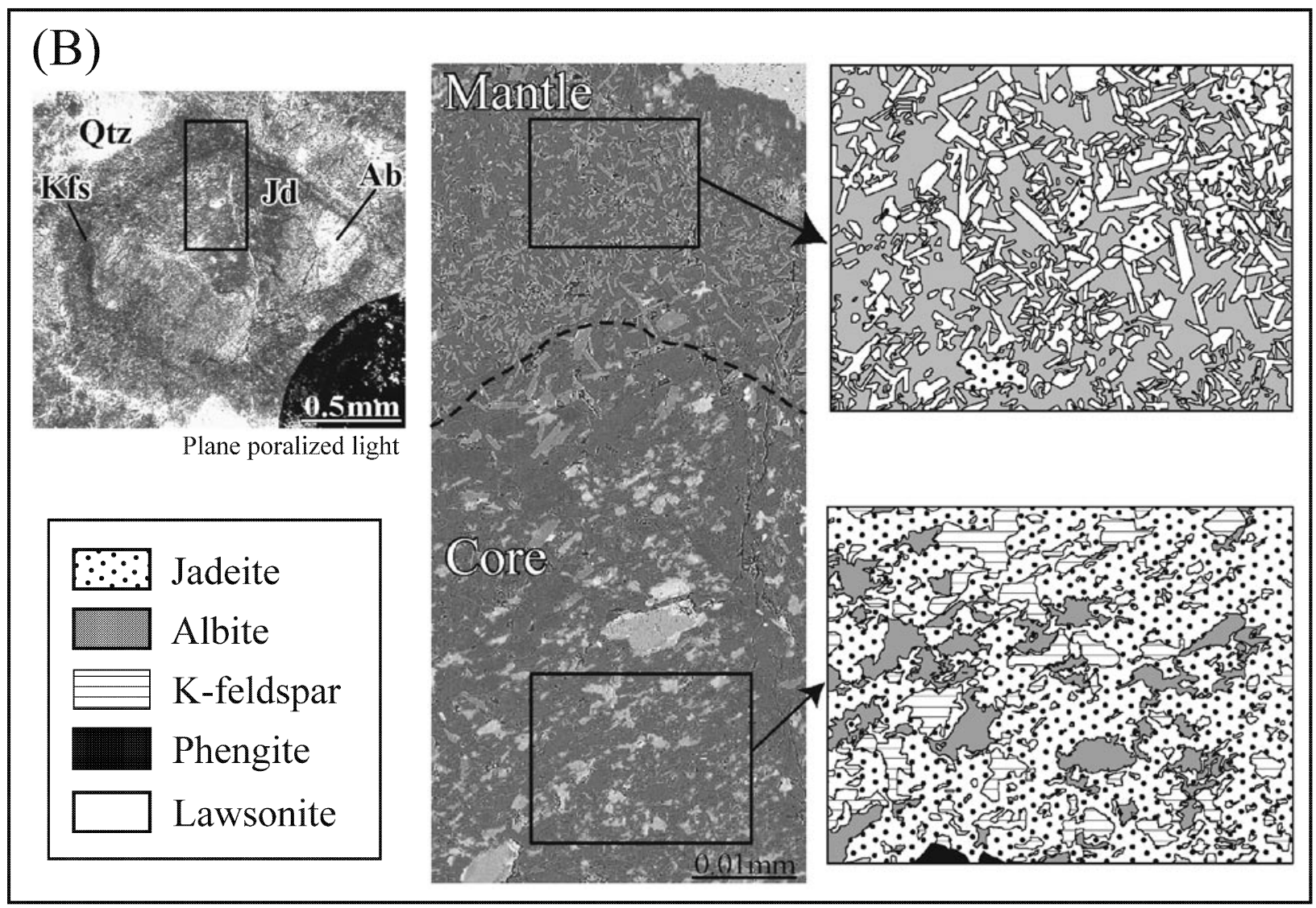

core consists of jadeite $\left(\mathrm{Jd}_{98-99}\right), \mathrm{K}$-feldspar, albite, quartz, phengite, sonite, albite, $\mathrm{K}$-feldspar, phengite, and quartz. The degree of albitithe mantle than in the rim. (B) The core consists of jadeite $\left(\mathrm{Jd}_{98-100}\right)$, jadeite $\left(\mathrm{Jd}_{96-100}\right)$, lawsonite, albite, $\mathrm{K}$-feldspar, and phengite. This ably incorporated in the later stage albitization.

pseudomorphs. It is heterogeneous, and $\mathrm{FeO}$ and $\mathrm{Na}_{2} \mathrm{O}$ contents vary from 2.5-7.0 wt \% and from 0-0.7 wt\%, respectively. Phengite in the matrix is partly replaced by $\mathrm{K}$-feldspar.

$\mathbf{K}$-feldspar. Relatively large crystals occur in contact with feldspar pseudomorphs, as a fine-grained variety within them, and as a replacement after phengite. Regardless of the modes of occurrence, the orthoclase, albite, and anorthite components are 98-96, 1-3, and 0-1 mol\%, respectively (Table 1).

Other minerals. Jadeitic pyroxene is partly replaced by albite, of which albite components being more than 99 mol\%. The textural relations suggest that albite is a late stage product. Garnet is rarely found as an aggregate of small euhedral grains in the pseudomorphs. The grossular content is $94.1-98.5 \mathrm{~mol} \%$, and the core of garnet is slightly richer in Fe than the rim. Very small amounts of pumpellyite are rarely recognized in the rim. Euhedral to subhedral titanite $50-100 \mu \mathrm{m}$ in length is common. Rutile grains rimmed by titanite occur rarely. Subhedral zircon up to $50 \mu \mathrm{m}$ in diameter is not uncommon in the matrix.

\section{DISCUSSION}

\section{Origin of the jadeite-quartz-K-feldspar rocks}

The jadeite-quartz- $\mathrm{K}$-feldspar rocks found in the Osamunai-Horonai River of the Kamuikotan Gorge area have an unusual texture of feldspar pseudomorphs. The mineral associations in the core and rim of the pseudomorphs suggest that they were initially $\mathrm{K}$-feldspar mantled by plagioclase. This type of feldspar is common in rapakivi 


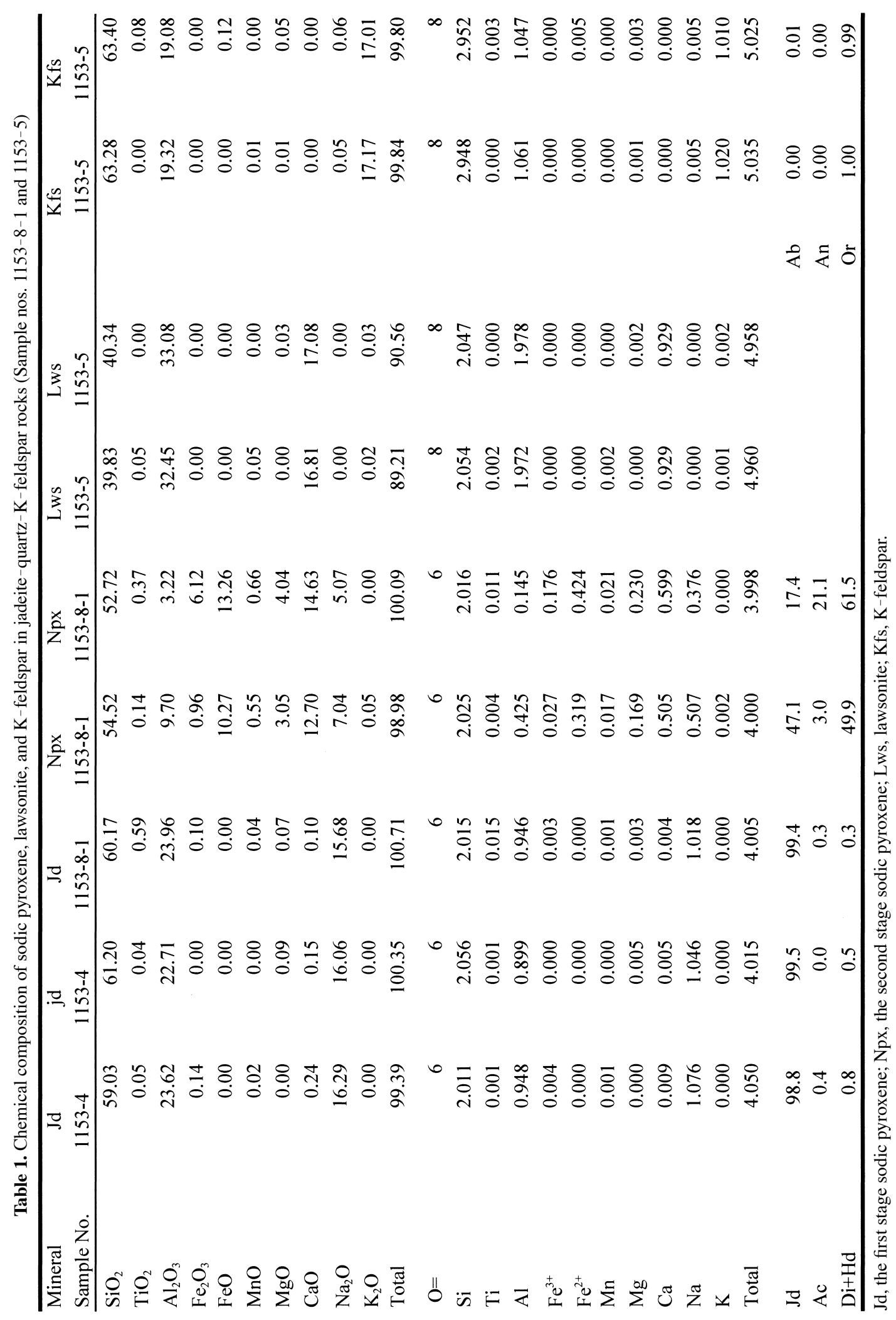


Table 2. Bulk rock composition of jadeite-quartz-K-feldspar rocks and rapakivi granite from other areas

\begin{tabular}{lrrrrr}
\hline & \multicolumn{2}{c}{ Jadeite-quartz-K-feldspar rocks } & \multicolumn{2}{c}{ Rapakivi granite } \\
& \multicolumn{1}{c}{$1153-1$} & $1153-4$ & \multicolumn{1}{c}{$1153-5$} & Ashizuri* & Finland** \\
\hline $\mathrm{SiO}_{2}$ & 76.63 & 75.74 & 77.70 & 64.83 & 76.20 \\
$\mathrm{TiO}_{2}$ & 0.12 & 0.13 & 0.10 & 0.97 & 0.22 \\
$\mathrm{Al}_{2} \mathrm{O}_{3}$ & 13.14 & 13.20 & 13.34 & 15.50 & 11.50 \\
$\mathrm{Fe}_{2} \mathrm{O}_{3}$ & 1.18 & 1.45 & 0.70 & 1.78 & - \\
$\mathrm{FeO}$ & - & - & - & 3.13 & 2.17 \\
$\mathrm{MnO}$ & 0.03 & 0.03 & 0.00 & 0.13 & 0.12 \\
$\mathrm{MgO}$ & 0.42 & 0.45 & 0.23 & 1.02 & 0.43 \\
$\mathrm{CaO}$ & 0.70 & 0.89 & 0.54 & 2.74 & 2.63 \\
$\mathrm{Na}{ }_{2} \mathrm{O}$ & 5.81 & 5.52 & 5.11 & 4.18 & 2.31 \\
$\mathrm{~K}_{2} \mathrm{O}$ & 2.13 & 1.95 & 2.46 & 5.07 & 5.64 \\
$\mathrm{P}_{2} \mathrm{O}_{5}$ & 0.09 & 0.09 & 0.10 & 0.14 & 0.04 \\
$\mathrm{Total}$ & 100.25 & 99.45 & 100.28 & 99.49 & 101.26 \\
\hline
\end{tabular}

${ }^{*}$ Murakami and Imaoka (1985).

** Bagdassarov and Dorfman (1998).

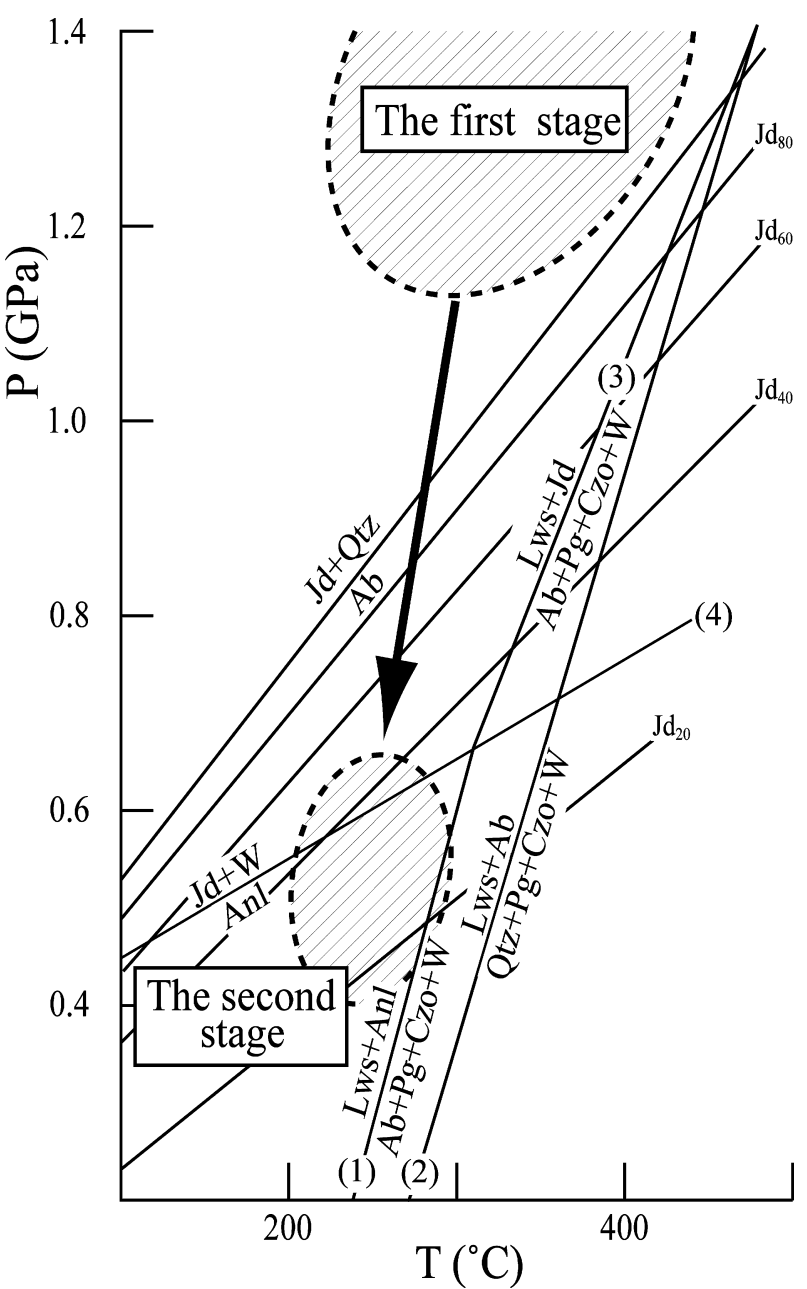

Figure 5. Approximate metamorphic conditions of the first and second stage metamorphism. The reactions (1)-(4) are after Harlow (1994). The $\mathrm{X}_{\mathrm{Jd}}$ isopleths are calculated using the thermodynamic data set of Holland and Powell (1998). Ab, albite; Anl, analcime; Czo, clinozoisite; Jd, jadeite; Lws, lawsonite; Pg, paragonite; Qtz, quartz; W, $\mathrm{H}_{2} \mathrm{O}$. granite from northern Europe. Fine-grained but similar feldspar also occurs in the granite of Cape Ashizuri, Japan. It is highly probable that the protoliths of the rocks in the study area were granitic with a rapakivi feldspar.

Brownish dusty aggregate clusters of $0.05-0.1 \mathrm{~mm}$ diameter are often recognized in the jadeite-quartz- $\mathrm{K}^{-}$ feldspar rocks. As the aggregate is a mixture of finegrained titanite, ilmenite, phengite, and actinolite, it may have originally been biotite.

The bulk rock analysis indicates that the rocks contain 75-77 wt $\% \mathrm{SiO}_{2}, 5.1-5.8 \mathrm{wt} \% \mathrm{Na}_{2} \mathrm{O}$, and 2.0-2.5 wt $\% \mathrm{~K}_{2} \mathrm{O}$. Similar to the metaplagiogranites Takayama (1986) found in the Etanbetsu-Daihassen River, they are leucocratic, but are different from the metaplagiogranites in that they are rich in $\mathrm{SiO}_{2}$, lack a glaucophane-rich component, are relatively rich in $\mathrm{K}_{2} \mathrm{O}$, and contain significant amounts of $\mathrm{K}$-feldspar (Table 2). The $\mathrm{K}_{2} \mathrm{O}$ content is low in comparison with rapakivi granite from other areas shown in Table 2, probably due to depletion during the metamorphism.

As shown in Figure 2, the occurrence of $\mathrm{K}$-feldspar is clearly limited to the areas in contact with feldspar pseudomorphs, whereas in the matrix it cannot be found and only small amounts of phengite exist. Therefore, $\mathrm{K}_{2} \mathrm{O}$ in primary $\mathrm{K}$-feldspar in the matrix may have migrated elsewhere. Taking account of the rather small size of the feldspar pseudomorphs, they may have been hypabyssal fine-grained granite or granite porphyry derived from continental crust or island-arc near the continent.

\section{Metamorphic conditions}

Two stages of metamorphism are recognized in the jadeite-quartz-K-feldspar rocks. The first stage is reflected 
by the minerals that fill the feldspar pseudomorphs, and is characterized by the equilibrium association of jadeite $\left(\mathrm{Jd}_{95-100}\right)$, quartz, lawsonite, and $\mathrm{K}$-feldspar. In Figure 5, the reaction curve, lawsonite + jadeite $=$ quartz + paragonite + clinozoisite + water, gives an upper temperature limit to the metamorphic conditions of the first stage, and the reaction curve, jadeite + quartz $=$ albite, gives a lower pressure limit.

The metamorphic conditions are therefore roughly estimated at $250-350{ }^{\circ} \mathrm{C}$ and more than $1.1 \mathrm{GPa}$.

Second stage metamorphism is detected from the appearance of sodic pyroxene $\left(\mathrm{Jd}_{10-35}\right)$, sodic-calcic amphibole, and pumpellyite. Sodic pyroxene is often found at the rim of first stage sodic pyroxene. As the second stage, pyroxenes are not pure jadeite; pressure conditions during the second stage metamorphism may have extended below the reaction curve, jadeite + water $=$ analcime. The composition of sodic pyroxene coexisting with albite and quartz gives an approximate pressure condition of 0.4-0.7 GPa. Conditions for the second stage metamorphism are estimated as $200-300{ }^{\circ} \mathrm{C}$ and $0.4-0.7 \mathrm{GPa}$.

\section{Significance of jadeite-quartz-K-feldspar rocks in the Kamuikotan zone}

Jadeite- and $\mathrm{K}$-feldspar-bearing metagranites are well known in eclogite facies terranes, such as the Western Alps (e.g., Biino and Compagnoni, 1992), but are not known to occur in the blueschist facies. Blueschist facies metaphonolites with jadeite- $\mathrm{K}$-feldspar-lawsonite paragenesis were found in northwest Turkey (Okay, 1997). This author concluded that the paragenesis is stable and the rare occurrence of $\mathrm{K}$-feldspar in blueschist facies rocks is ascribed to the unusual rock compositions required to form this mineral. In the jadeite-quartz-K-feldspar rocks in the study area, $\mathrm{K}$-feldspar is unevenly distributed, and is found only near pseudomorphs of feldspar. Although the $\mathrm{K}_{2} \mathrm{O}$ content of the rocks is relatively low, $\mathrm{K}^{-}$ feldspar is considered to have recrystallized exclusively in the $\mathrm{K}_{2} \mathrm{O}$-rich vicinity near primary $\mathrm{K}$-feldspar.

$\mathrm{K}$-feldspar-bearing granitic rocks have never been reported from the Kamuikotan zone. The finding of jadeite-quartz- $\mathrm{K}$-feldspar rocks in the zone provides important information about the source of metamorphic protoliths. The inference is that these materials formed through the activity of felsic magma present near the trench during Late Jurassic to Cretaceous times. Granitic rocks were supplied to the trench from a developed island-arc or con- tinent, dragged down into the deep crust and changed into jadeite-quartz-K-feldspar rocks during the first stage of metamorphism. Thereafter, the rocks were uplifted in a serpentinite diapir to a region where a lower-grade second stage metamorphism widely prevailed.

\section{ACKNOWLEDGMENTS}

We express our sincere thanks to Yoshiaki Tainosho for his valuable comments. The manuscript has benefited from critical reviews by Hideo Ishizuka, Aral I. Okay, and Masaki Enami. This study was supported in part by a 2004 Fukada-in-Aid of FGI from the Fukada Geological Institute to Y.O.

\section{REFERENCES}

Bagdassarov, N. and Dorfman, A. (1998) Viscoelastic behavior of partially molten granites. Tectonophysics, 290, 27-45.

Biino, G.G. and Compagnoni, R. (1992) Very-high pressure metamorphism of the Brossasco coronite metagranite, southern Dora Maira Massif, Western Alps. Schweizerische Mineralogische und Petrographische Mitteilungen, 72, 347-63.

Gouchi, N. (1983) Kamuikotan metamorphic rocks in the Kamuikotan gorge area, west of Asahikawa, Hokkaido. The Journal of the Japanese Association of Mineralogists, Petrologists and Economic Geologists, 78, 383-393.

Harlow, G.E. (1994) Jadeitites, albitites and related rocks from the Motagua fault zone, Guatemala. Journal of Metamorphic Geology, 12, 49-68.

Holland, T.J.B. and Powell, R. (1998) An internally consistent thermodynamic data set for phases of petrological interest. Journal of Metamorphic Geology, 16, 309-343.

Maekawa, H. (1989) Two modes of mixing of Biei ophiolitic mélange, Kamuikotan blueschist belt, Japan. Journal of Geology, 97, 93-108.

Murakami, N. and Imaoka, T. (1985) Rapakivi granite from cape of Ashizuri, Kohchi Prefecture, Southwest Japan. The Journal of the Geological Society of Japan, 91, 179-194.

Okay, A.I. (1997) Jadeite-K-feldspar rocks and jadeitites from northwest Turkey. Mineralogical Magazine, 61, 835-843.

Sakakibara, M. and Ota, T. (1994) Metamorphic evolution of the Kamuikotan high-pressure and low-temperature metamorphic rocks in central Hokkaido, Japan. Journal of Geophysical Research, 99, 22221-22235.

Takayama, M. (1986) Mode of occurrence and significance of jadeite in the Kamuikotan metamorphic rocks, Hokkaido, Japan. Journal of Metamorphic Geology, 4, 445-454.

Manuscript received August 31, 2006

Manuscript accepted November 1, 2006

Published online December 27, 2006

Manuscript handled by Masaki Enami 